\title{
PREDIKSI ALOKASI JUMLAH PRODUKSI MINYAK SAWIT DENGAN METODE REGRESI LINIER BERGANDA PADA PT. PALM LAMPUNG PERSADA
}

\author{
Sidik Rahmatullah ${ }^{1}$, Dita Destia ${ }^{2}$ \\ Program studi Teknik Komputer ${ }^{1}$,Program studi Sistem Informasi ${ }^{2}$ \\ STMIK Dian Cipta Cendikia Kotabumi \\ Jl.Negara No.03 Candimas, lampung Utara \\ sidik@dcc.ac.id1
}

\begin{abstract}
ABSTRAK
PT. Palm Lampung Persada Way Kanan merupakan suatu perusahaan yang bergerak dalam bidang perkebunan kelapa sawit yang menghasilkan minyak sawit mentah. Perusahaan ini sering mengalami permasalahan dalam hal alokasi produksi minyak sawit.

Penelitian ini dilakukan dengan menggunakan metode regresi linier berganda untuk memprediksi alokasi jumlah produksi minyak sawit berdasarkan data pembelajaran dengan menggunakan Microsft Excel 2010 dan aplikasi RapidMiner. Dalam penelitian ini terdapat variabel dependen (bebas) dan variable independent (terikat) yaitu : variable dependen (bahan baku, jumlah tenaga kerja, curah hujan dan luas lahan) sedangkan variable independent (minyak sawit).

Perhitungan dengan mnggunakan metode regresi linier berganda dalam menentukan alokasi jumlah produksi minyak sawit dapat digunakan untuk membantu perusahaan dalam mengambil sebuah keputusan dengan nilai prediksi yang mendekati dengan data asli yang diolah sebagai data pembelajaran dengan hasil 170,811 dan data asli sebesar 170 dan nilai error sebesar 0,002 .
\end{abstract}

Kata kunci: regresi linier berganda, Microsoft excel 2010, rapidminer 


\section{ABSTRACT}

PT. Palm Lampung Persada Way Kanan is a company engaged in oil palm plantations that produce crude palm oil. This company often experiences problems in the allocation of palm oil production.

This research was conducted using multiple linear regression method to predict the allocation of the amount of palm oil production based on learning data using Microsft Excel 2010 and RapidMiner applications. In this study there are dependent variables (free) and independent variables (bound), namely: dependent variable (raw material, amount of labor, rainfall and land area) while the independent variable (palm oil).

Calculations using multiple linear regression methods in determining the allocation of the amount of palm oil production can be used to assist companies in making a decision with predictive value close to the original data processed as learning data with a result of 170.811 and original data of 170 and an error value of 0.002 .

Keywords: regesi liner berganda, Microsoft excel 2010, rapidminer. 


\section{PENDAHULUAN}

Indonesia merupakan negara agraris, potensi ini didukung oleh faktor-faktor alam seperti iklim dan tanahnya yang subur. Sektor pertanian di Indonesia memiliki peranan yang cukup penting dalam perekonomian negara karena kegiatan agroindustri yang berbasis pertanian mampu memberikan devisa bagi negara. Kelapa sawit merupakan sebagai salah satu komoditi unggulan dalam sector pertanian di Indonesia, tanaman tropis ini yang dikenal sebagai penghasil minyak sawit.

Pada PT. Palm Lampung Persada ini memproduksi minyak sawit mentah yang di tentukan oleh bahan baku, curah hujan, jumlah tenaga kerja dan luas lahan. Didalam memproduksi, PT. Palm Lampung Persada sering mengalami permasalahan dalam hal alokasi bahan baku untuk memproduksi minyak sawit. Seiring dengan berkembangnya suatu perusahaan, akan berdampak pula pada semakin tingginya aktifitas perusahaan, baik aktivitas di manajemen puncak maupun aktivitas para staf karyawan perusahaan. Seluruh pihak dipacu untuk mencapai tujuan perusahaan dengan berdasarkan pada program yang telah dibuat oleh manajemen perusahaan. Untuk mencapai tujuannya, suatu perusahaan harus memiliki sistem yang terdiri dari struktur penataan organisasi, wewenang, tanggung jawab dan konsepsi informasi sehingga memudahkan pelaksanaan pengendalian dan suatu proses atau seperangkat tindakan yang dilakukan untuk memastikan bahwa organisasi bekerja untuk mencapai tujuannya.

Untuk menghadapi masalah yang dihadapi oleh perusahaan tersebut maka dirancang lah sebuah system dengan menggunakan analisa regresi linier berganda. Penulis menggunakan analisis regresi linier berganda karena dengan metode ini perusahaan bisa menganalisis produksi untuk tahun berikutnya

\section{METODOLOGI PENELITIAN}

Adapun teknik perhitungan yang dipakai adalah regresi linier berganda serta menggunakan perhitungan dengan Microsoft Excel 2010 dan Rapidminer 5.3. Adapun Tahapan perhitungan regresi linier berganda adalah sebagai berikut :

\subsection{Pengumpulan Data}

Pada tahapan ini penulis mendapatkan data langsung dari PT. Palm Lampung Persada, data-data tersebut seperti data produksi mulai dari data yang mempengaruhi produksi seperti bahan baku, jumlah tenaga kerja, curah hujan, daan luas lahan. 


\subsection{Analisis}

Pada tahapan ini penulis mengelompokkan data-data yang didapat. Pengelompokkan dimulai dengan menentukan variable independent dan variable dependen. Adapun variable tersebut sebagai berikut :

1. Variabel Bebas ( variabel independen) Variabel independen adalah variabel yang menjelaskan atau mempengaruhi variabel lain yaitu : Bahan Baku (ton) ( $\left.\mathrm{X}_{1}\right)$, Jumlah Tenaga Kerja (org) $\left.\mathrm{X}_{2}\right)$, Curah Hujan (mm) $\left(\mathrm{X}_{3}\right)$ dan Luas Lahan (ha) $\left(\mathrm{X}_{4}\right)$

2. Variabel Terikat ( variabel dependen) Variabel terikat ( dependen ) adalah variabel yang jelas atau dipengaruhi oleh variabel independent yaitu Minyak Sawit (Y).

\subsection{Perhitungan Menggunakan}

\section{Microsoft Excel}

Pada tahap ini penulis menggunakan perhitungan manual dengan Microsoft excel 2010 dengan rumus hasil akhir adalah sebagai berikut :

$\mathrm{Y}=\mathrm{a}+\mathrm{b} 1 \mathrm{x} 1+\mathrm{b} 2 \mathrm{x} 2+\mathrm{b} 3 \mathrm{x} 3+\mathrm{b} 4 \mathrm{x} 4$

Dimana :

$\mathrm{Y}=$ minyak sawit

$a=$ konstanta

b1, b2, b3 dan b4 = koefisien

$\mathrm{x} 1$ = bahan baku

$\mathrm{x} 2=$ jumlah tenaga kerja

x3 = curah hujan $\mathrm{x} 4=$ luas lahan

\subsection{Perhitungan Nilai Error}

Rumus: $\frac{(Y i+\grave{Y} i)-n}{n} \times 100 \%$

Keterangan :

Yi = Data awal ( data sebenarnya )

$\grave{Y} \mathrm{i}=$ Data akhir ( data hasil estimasi )

$\mathrm{n}=$ jumlah data

Ỳi didapat dari persamaan regresi $\mathrm{Y}=$ $144,6429842+(-0,003938341) \mathrm{X}_{1}+$ $(-0,000450161) X_{2}+0,032116944$ $\mathrm{X}_{3}+0,380945046 \mathrm{X}_{4}$ dengan memasukkan $\mathrm{X}_{1}$ (bahan baku), $\mathrm{X}_{2}$ (Jumlah Tenaga Kerja), $X_{3}$ (Curah Hujan) dan $\mathrm{X}_{4}$ (Luas Lahan) ke dalam persamaan tersebut.

\section{HASIL DAN PEMBAHASAN}

\subsection{Hasil}

Berikut proses perhitungan prediksi alokasi jumlah produksi minyak sawit dengan metode regresi linier berganda menggunakan Microsoft Excel 2010 dan Aplikasi RapidMiner. Dengan informasi dari data pembelajaran tahun 2017 sebagai berikut:

1. Bahan baku paling sedikit $=60$ Ton dan bahan baku terbanyak $=90$

2. Jumlah tenaga kerja paling sedikit $=600$ dan jumlah tenaga kerja terbanyak $=800$ 
3. Curah hujan teringan $=1,8 \mathrm{~mm}$ dan Curah hujan terlebat $=987,6 \mathrm{~mm}$

4. Luas Lahan terkecil $=20$ ha dan luas lahan terluas $=30$ ha

5. Alokasi produksi minyak sawit paling sedikit $=150$ ton dan alokasi produksi minyak sawit terbanyak $=$ 171 ton.

\subsubsection{Perhitungan menggunakan}

\section{Microsoft Excel 2010}

Berikut ini adalah gambar tampilan awal untuk melakukan prediksi alokasi jumlah produksi minyak sawit. Yaitu data set atau data latih.

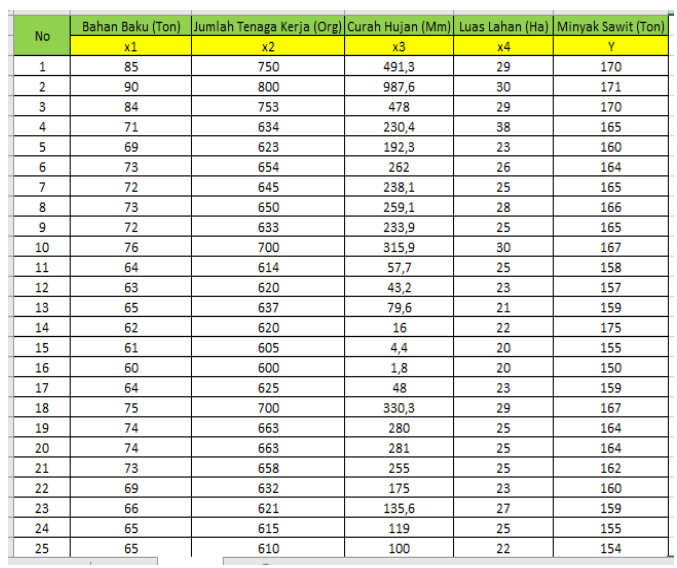

Gambar 1. Data Set / Data Latih

\begin{tabular}{|c|c|c|c|c|c|c|}
\hline \multicolumn{7}{|c|}{ 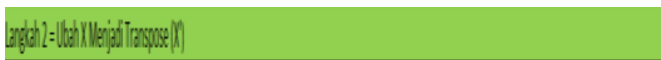 } \\
\hline \multicolumn{7}{|c|}{$x$} \\
\hline 1 & 1 & 1 & 1 & 1 & 1 & 1 \\
\hline 85 & n & \& & 11 & $\theta$ & $B$ & 12 \\
\hline 78 & 80 & 73 & 64 & 623 & 64 & 6.5 \\
\hline 19.13 & 98,6 & 48 & B214 & 19,3 & 162 & $28 x \mid$ \\
\hline$\theta$ & 30 & $\theta$ & 38 & B & 16 & 15 \\
\hline
\end{tabular}

Gambar 2. Tampilan Perubahan X

MenjadiX

\begin{tabular}{|c|c|c|c|c|}
\hline \multicolumn{5}{|c|}{ 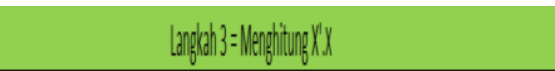 } \\
\hline \multicolumn{5}{|c|}{$x^{\prime \prime x}$} \\
\hline 350 & 25590 & 1331894 & 67374,2 & 8752 \\
\hline 24596 & 1719318 & 1637650 & 4924799,4 & 619520 \\
\hline 3318949 & 16076570 & 159703350 & 45449967,4, & 5026731 \\
\hline 657342,2 & 4924799,4 & 45419467,4 & 197106060,62 & 17779998 \\
\hline 8752 & 619520 & 5867313 & 177790998 & 222200 \\
\hline
\end{tabular}

Gambar 3. Tampilan Perkalian X’.X

\begin{tabular}{|c|c|c|c|c|c|}
\hline \multicolumn{5}{|c|}{ 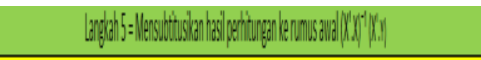 } & \multirow{3}{*}{$\frac{1.1}{5 \times 0}$} \\
\hline \multicolumn{5}{|c|}{$|X X|^{-1}$} & \\
\hline 1.25060145 & 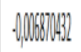 & amsorsis & 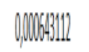 & Monos: & \\
\hline 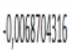 & 0,00120165 & 4006073 & 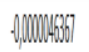 & 19021207 & 39550 \\
\hline 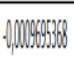 & 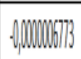 & 200010212 & 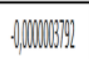 & quari11. & 30601012 \\
\hline 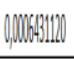 & 40006567 & ancosisy & anowsi21] & 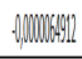 & 106004 \\
\hline 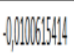 & 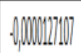 & anowill & amomagy. & 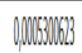 & 101020 \\
\hline
\end{tabular}

Gambar 4. Tampilan hasil mensubtitusikan perhitungan

\begin{tabular}{|c|c|c|}
\hline \multicolumn{3}{|c|}{ HASIL } \\
\hline Minyak Sawit(Ton) & 144,6429842 & Intercept \\
\hline Bahan Baku (Ton) & $-0,003938341$ & Koe 1 \\
\hline Jumlah Tenaga Kerja (org) & $-0,000450161$ & Koe 2 \\
\hline Curah Hujan (mm) & 0,032116944 & Koe 3 \\
\hline Luas Lahan (ha) & 0,380945046 & Koe 4 \\
\hline
\end{tabular}

Gambar 5.Tampilan Hasil Perhitungan 
Setelah melakukan perhitungan diatas dan mendapatkan nilai a, b1, b2, b3 dan b4 maka untuk membuktikan hasil prediksi alokasi produksi minyak sawit maka digunakan lah rumus sebagai berikut:

\begin{tabular}{|c|c|c|c|}
\hline \multicolumn{2}{|c|}{$y=0+b x x+62 x+633(3+64 x 4$} & \multicolumn{2}{|c|}{1902299673} \\
\hline 68 & 678 & 491,3 & 30 \\
\hline
\end{tabular}

Nilai Error $=\frac{(170+170,811)-350}{350} \mathrm{x}$ $100 \%=0,002$.

\subsubsection{Perhitungan menggunakan}

\section{Rapidminer 5.3}

Setelah kita mencari nilai dengan perhitungan menggunakan Microsoft Excel 2010, kemudian kita implementasikan data tersebut kedalam aplikasi rapidminer. Berikut gambar tampilan awal prediksi alokasi jumlah produksi dengan menggunakan rapidminer 5.3.

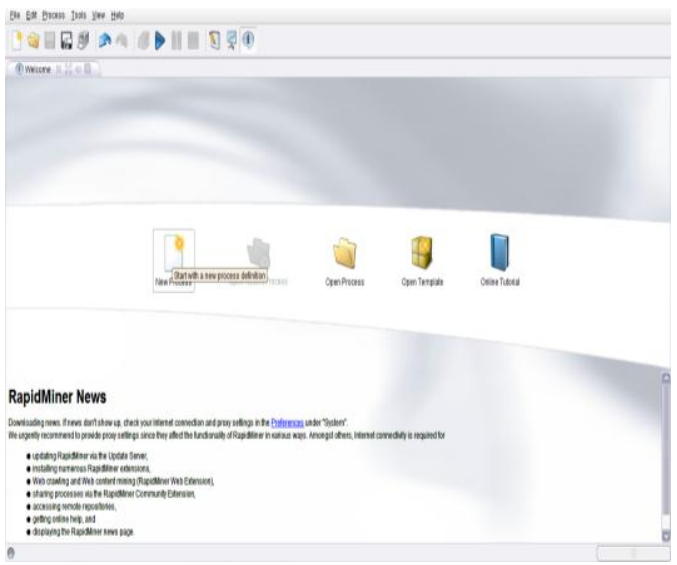

Gambar 9. Tampilan Awal RapidMiner

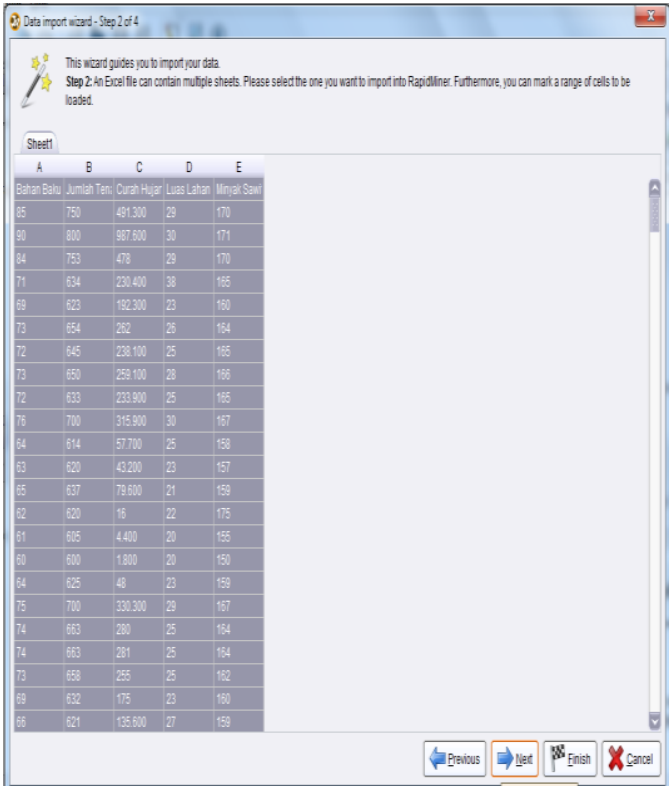

Gambar 21. Tampilan Penginputan Data Set dan Data Uji

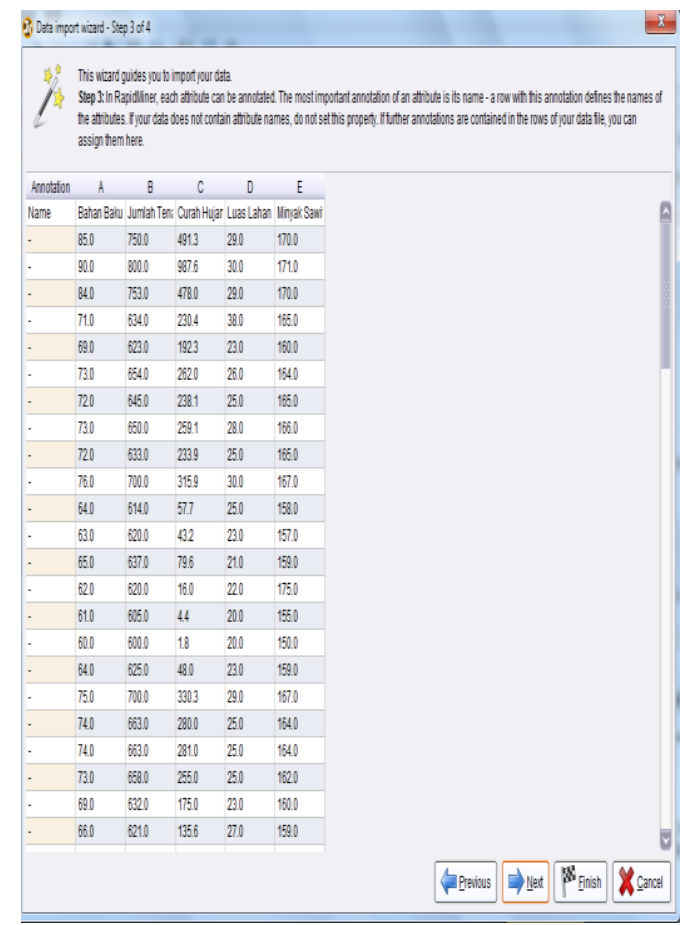

Gambar 22. Tampilan Perubahan Data Uji 


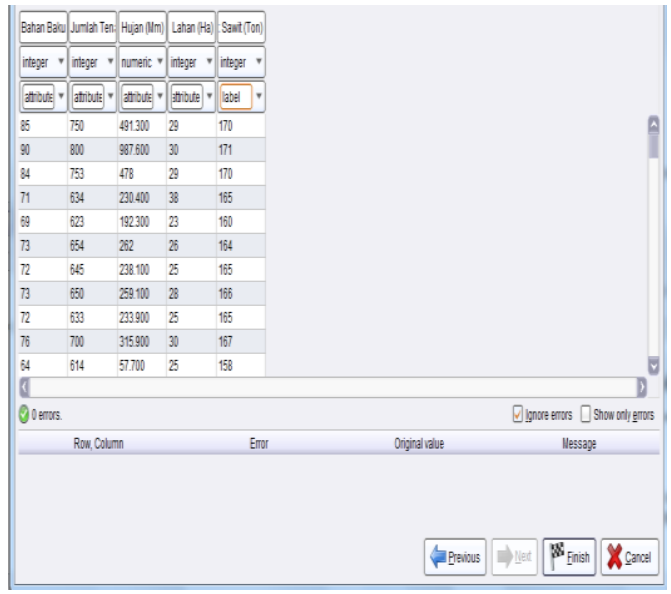

Gambar 23. Tampilan Pengubah Attribute Menjadi Label

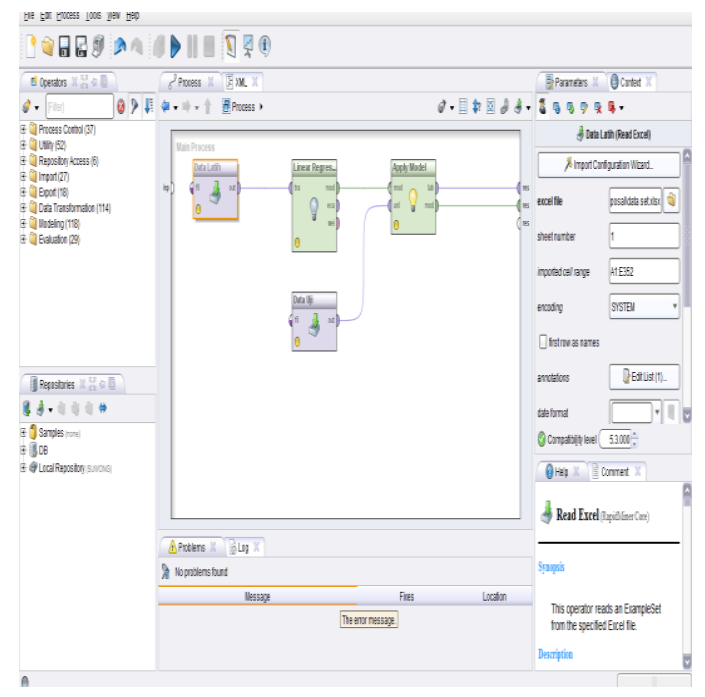

Gambar 25. Tampilan Proses View

\begin{tabular}{|c|c|c|c|c|c|c|}
\hline Row No. & Minyak Saw & predictions. & Banan Bak & Jumbah Ten & Curan Huja & Luas Lahan \\
\hline 1 & 170 & 170.811 & 85 & 750 & 491.300 & 29 \\
\hline 2 & 171 & 187.000 & 90 & 800 & 987.600 & 30 \\
\hline 3 & 170 & 170.387 & 84 & 753 & 478 & 29 \\
\hline 4 & 165 & 165.921 & 71 & 634 & 230.400 & 38 \\
\hline 5 & 160 & 159.006 & 69 & 623 & 192.300 & 23 \\
\hline 6 & 164 & 162.367 & 73 & 654 & 262 & 26 \\
\hline 7 & 165 & 161.225 & 72 & 645 & 238.100 & 25 \\
\hline 8 & 166 & 163.034 & 73 & 650 & 259.100 & 28 \\
\hline 9 & 165 & 161.092 & 72 & 633 & 233.900 & 25 \\
\hline 10 & 167 & 185.604 & 76 & 700 & 315.900 & 30 \\
\hline 11 & 158 & 155.479 & 64 & 614 & 57.700 & 25 \\
\hline 12 & 157 & 154.257 & 63 & 620 & 43200 & 23 \\
\hline 13 & 159 & 154.656 & 65 & 637 & 79.600 & 21 \\
\hline 14 & 175 & 153.011 & 62 & 620 & 16 & 22 \\
\hline 15 & 155 & 151.881 & 61 & 605 & 4.400 & 20 \\
\hline 16 & 150 & 151,798 & 60 & 600 & 1.800 & 20 \\
\hline 17 & 159 & 154.410 & 64 & 625 & 48 & 23 \\
\hline 18 & 167 & 165.683 & 75 & 700 & 330.300 & 29 \\
\hline 19 & 164 & 162.560 & 74 & 663 & 280 & 25 \\
\hline
\end{tabular}

Gambar 26. Tampilan Hasil Predksi

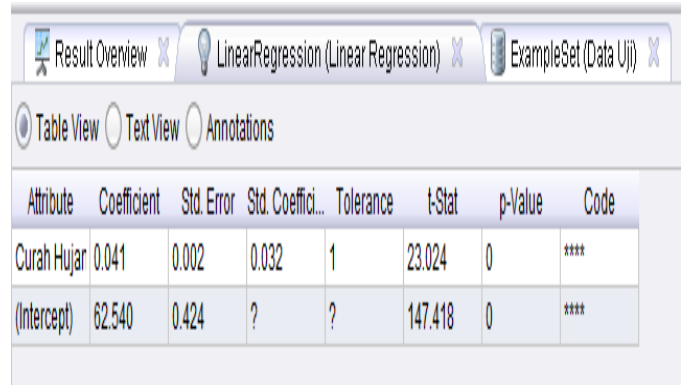

Gambar 27. Tampilan Nilai Error

\subsection{Pembahasan}

Berdasarkan hasil yang diperoleh dari prediksi alokasi jumlah produksi minyak sawit yang mengacu pada data tahun 2017 dengan dilakukan sebanyak 350 kali prediksi menunjukan bahwa perhitungan prediksi regresi linier berganda memiliki masing-masing pengaruh yaitu pengaruh dari bahan baku (x1) adalah sebesar 0,424, pengaruh dari jumlah tenaga kerja (x2) adalah sebesar 0,073 , pengaruh dari curah hujan (x3) adalah sebesar 0,002 sedangkan pengaruh dari luas lahan adalah sebesar 0,065. Jadi dari ke empat variable tersebut yang paling berpengaruh pada produksi minyak sawit adalah curah hujan (x3) sebesar 0,002 .

\section{PENUTUP}

Berdasarkan pembahasan mengenai Prediksi Alokasi Jumlah Produksi Minyak Sawit dengan Metode Regresi Linier Berganda bedasarkan data latih tahun 2017, maka dapat disimpulkan : 
1. Perhitungan prediksi menggunakan metode regresi linier berganda adalah metode yang cocok untuk memprediksi alokasi jumlah produksi minyak sawit yang dilihat dari nilai error absolute yang dihasilkan dari prediksi tersebut.

2. Dengan perhitungan metode regres linier berganda dapat menjadi solusi bagi perusahaan dalam mengatasi masalah ketidaksatabilan dalam hal produksi minyak sawit.

3. Hasil penelitian menunjukkan bahwa perbedaan variable yang digunakan berpengaruh terhadap hasil prediksi alokasi jumlah produksi minyak sawit terhadap nilai error absolute yang berbeda.

4. Perhitungan prediksi dengan menggunakan metode regresi linier berganda dalam menentukan jumlah produksi minyak sawit menghasilkan rata-rata memiliki tingkat kebenaran prediksi sebagai berikut : bahan baku (x1) adalah sebesar 0,424, jumlah tenaga kerja (x2) adalah sebesar 0, 073, curah hujan (x3) adalah sebesar 0,002 sedangkan luas lahan adalah sebesar 0,065. Jadi dari ke empat variable tersebut yang paling berpengaruh pada produksi minyak sawit adalah curah hujan (x3) sebesar 0,002.

\section{DAFTAR PUSTAKA}

[1] Syarifuddin, M., et al. (2014). Metode Regresi Linier Untuk Prediksi Kebutuhan Energi Listrik Jangka Panjang (Studi Kasus Provinsi Lampung). Jurnal Informatika dan Teknik Elektro Terapan, 2(2).

[2] Herawati, H., et al. (2016). Pengaruh Kualitas Bahan Baku dan Proses Produksi Terhadap Kualitas Produk pada UD. Tahu Rosydi Puspan Maron Probolinggo.UNEJ eProceeding, 463-482.

[3] Sarwati, A., et al.. (2017). Pengaruh Modal Usaha, Biaya Bahan Baku dan Tenaga Kerja Terhadap Kinerja Usaha Industri Tahu di Kabupaten Sukoharjo. Jurnal of Management $3(3)$.

[4] Susanto. E., et al. (2014). Respon Pertumbuhan dan Hasil Tanaman Ubi Jalar (Ipomoea Batatas L.) Pada Beberapa Macam dan Waktu Aplikasi Bahan Organik. Jurnal Produksi Tanaman, 2(5).

[5] Pratiwi, W. H. S., et al (2015). Pemahaman mahasiswa Atas Metode Penelitian Kualitatif. 
LiNGUA: Jurnal Ilmu Bahasa dan Sastra, 10(1), 18-23.

[6] Karina, A. D. (2015). Penerapan Algoritma Regresi Linier Berganda Pada Data Pabrik Gula Rendeng Kudus. Skripsi, Fakultas Ilmu Komputer.

[7] Chistie, D., Baskoro, D. A., et al. (2013). Belajar Data Mining Dengan RapidMiner.

[8] Widodo, H. K., et al. (2010). Sistem Supply Chain Crude-PalmOil Indonesia dengan Mempertimbangkan Aspek Economical Revenue, Social Welfare dan Environtment. Jurnal Teknik Industri, 12(1),47-54.

[9] Yusuf, H., et al. (2014). Analisis Faktor-Faktor yang Mempengaruhi Produksi Jagung Di Kabupaten Aceh Tenggara. Jurnal Agribisnis Sumatera Utara. 7(2).

[10] Wahyuni, S., et al. (2017). Implementasi RapidMiner Dalam Menganalisa Data Mahasiswa Drop Out. Jurnal Abdi Ilmu, 10(2), 18991902.

[11] Gunawan, A., et al (2017). Analisis Penggunaan Smartphone Bagi
Mahasiswi Untuk Meningkatkan

Produktivitas Pendidikan.

Prosiding SENIATI, 3(2), 4-1.

[12] Simanjuntak, L. N., et al. (2014). Pengaruh Curah Hujan dari Hari Hujan Terhadap Produksi Kelapa Sawit Berumur 5, 10 dan 15 Tahun Di Kebun Begerpang Estate PT. PP London Sumatera Indonesia, Tbk. Jurnal Agroekoteknologi Universitas Sumatera Utara, 2(3).

[13] Alfayanti, Z. E. (2013). Analisis Faktor-Faktor Yang Mempengaruhi Produksi Kelapa Sawit Rakyat di Kabupaten Mukomuko. Jurnal Agrisep Universitas Bengkulu, 12(1). 